\title{
RECEPTION OF M. HEIDEGGER'S LEGACY IN ANALYTIC PHILOSOPHY
}

\section{Synytsia A. S.}

\section{INTRODUCTION}

Analytic philosophers, historically, have not often studied the ideas of representatives of other intellectual traditions. This was due to the specificity of the subject matter and methodology of analytic research. Cognition of the nature of things, phenomena, or processes in the world by means of analytic philosophy was based on the study of the peculiarities of the usage of language expressions. Analytic thinkers therefore primarily appealed to language as an empirical reality of thought rather than the predecessor's reasoning. It was thought that in order to solve a particular philosophical problem, one should clearly understand the meaning of the terms by which it was formulated. However, the history of analytic philosophy has witnessed many cases where, in order to better understand a particular issue or to demonstrate the benefits of its own method of research, representatives of analytic philosophy have turned to the work of continental philosophers. German philosopher M. Heidegger was one of the most frequently adressed.

There were several reasons for this. First, due to the specificity of their own methodology, analytic philosophers have rarely been interested in the history of philosophy. The concepts of previous philosophers seemed unsuitable for solving contemporary problems. The fact is that analytic philosophy is guided by scientific standards of philosophy - so it investigates only the latest ideas, takes into account empirical facts and complies with the requirements of scientific accuracy, objectivity, systematicness and validity. M. Heidegger was a contemporary of L. Wittgenstein, an Austrian thinker who formulated the foundations of analytic philosophy most comprehensively. They both grew up in a German-speaking background and began writing philosophical works at around the same time - in the mid-1910s. Nevertheless, M. Heidegger became famous a little later, since L. Wittgenstein's early key work appeared in 1921, and the work 
"Being and Time" that made M. Heidegger famous and extremely influential on the continent - in 1927. Second, methodological principles for the constructing of analytic philosophy, founded by G. Frege, and phenomenology, founded by E. Husserl, whose method was developed by his student M. Heidegger, were common, since both emphasized the importance of the notion of meaning as a medial term with ideal status in epistemology (although analytic philosophy appeal to language and phenomenology - to consciousness) and criticized psychologism in logic ${ }^{1}$. Probably this can be explained in particular by the interest to the problems of logic in early phenomenology. Third, the philosophical ideas of M. Heidegger, given their originality and essential difference from the thoughts of analytic philosophers, became the subject of particular attention and criticism on their part. After all, M. Heidegger, despite his interest in logical issues, developed a conception full of metaphors, which clearly does not meet the principles of scientific research. Moreover, he contrasted his own metaphysics with the sciences, because they became too separate and not inclined to seek for their only essential basis. This is the task of metaphysics, which can understand the basic principles of the Universe much more fully. Such a position was definitely unacceptable to analytic philosophers.

However, despite the long history of the reception of M. Heidegger's philosophical ideas in analytic philosophy, this topic has become of interest to researchers relatively recently. This can be explained by the need to investigate the origins and history of analytic philosophy. Such need arose at the end of the twentieth century, i. e., when analytic philosophy was broken down into a vast number of philosophical conceptions that were often contradictory to one another. And as it turned out, there was also place for interpretations of M. Heidegger's ideas in the history of analytic philosophy. Moreover, this topic became landmark, as evidenced by publications of P. Livingston ${ }^{2}$, L. Braver ${ }^{3}$, D. Egan, S. Reynolds, A. J. Wendland

1 See more: Синиця А. С. Розвиток дискусії між представниками континентальної і аналітичної філософії. Актуальні проблеми духовності: зб. наук. праць. 2016. Вип. 16. С. 36-47.

Livingston P. M. Wittgenstein Reads Heidegger, Heidegger Reads Witttgenstein: Thinking Language Bounding World. In: Beyond the AnalyticContinental Divide: Pluralist Philosophy in the Twenty-First Century / J. A. Bell, A. Cutrofello, P. M. Livingston (ed.). New York: Routledge, 2015. P. 222-248. 
(eds. $)^{4}$, M. Geier ${ }^{5}$, J. Robson ${ }^{6}$, M. Esfeld ${ }^{7}$, K. McDaniel ${ }^{8}$ and others. Each author thoroughtly discussed M. Heidegger's reception by individual analytic philosophers (espesially by L. Wittgenstein), although the overall analytic portrait of M. Heidegger remains somewhat blurred. Therefore, we will further find out why the assessment of this German thinker's legacy in analytic philosophy was extremely controversial - from negative (R. Carnap and A. Ayer) or neutral (G. Ryle, B. Russell) to positive (L. Wittgenstein, R. Rorty, G. Dreyfus), even though it arose almost simultaneously - in the late 1920 s and early 1930s.

\section{Negative reception}

This highly critical reception of the philosophical ideas and methodology of M. Heidegger became perhaps the most popular right in the beginning. It happened immediately after the publishing of R. Carnap's work "The Elimination of Metaphysics Through Logical Analysis of Language" (1931). Its author - one of the prominent representatives of the Vienna Circle - has applied the method of logical analysis to demonstrate the absurdity of metaphysics, paying particular attention to M. Heidegger's views. Since logical positivism was in its heyday in Europe at the time, Carnap's reception of M. Heidegger's legacy became very popular and widely known. Moreover, the author emigrated to the United States because of his political views in 1935. Many European intellectuals (analytic philosophers in particular) also arrrived there in a short while due to the events of World War II and shared his opinion. Ideas of analytic philosophy were much more developed in the United States than

${ }^{3}$ Braver L. Analyzing Heidegger: A History of Analytic Reactions to Heidegger. In: Interpreting Heidegger: Critical Essays / D. O. Dahlstrom (ed.). Cambridge: Cambridge University Press, 2011. P. 235-255.

4 Wittgenstein and Heidegger / D. Egan, S. Reynolds, A. J. Wendland (eds.). London: Routledge, 2013. 282 p.

5 Geier M. Wittgenstein und Heidegger: Die letzten Philosophen. Rowohlt E-Book, 2017. 448 s.

${ }^{6}$ Robson J. Heidegger and Analytic Philosophy: Together at Last? International Journal of Philosophical Studies. 2014. Vol. 22, Issue 3: Continental Engagement with Analytic Philosophy. P. 482-487.

7 Esfeld M. What can Heidegger's Being and Time Tell Today's Analytic Philosophy? Philosophical Explorations. 2001. Vol. 4. P. 46-62.

8 McDaniel K. Heidegger's Metaphysics of Material Beings. Philosophy and Phenomenological Research. 2013. Vol. 87. P. 332-337. 
concepts of continental philosophers. This was especially due to the fact that they could be combined with the American philosophy of pragmatism in the form of neo-pragmatism, while the ideas of continental philosophy remained unnoticed, and if they became known, it was thanks to criticism, proposed by R. Carnap in particular.

To demonstrate the absurdity of metaphysics, R. Carnap stated "a few sentences from that metaphysical school which at present exerts the strongest influence in Germany"9. As it turned out, these sentences were quotations from M. Heidegger's "What is Metaphysics?" (1929). Here they are (translated by A. Pap):

"What is to be investigated is being only and - nothing else; being alone and further - nothing; solely being, and beyond being - nothing. What about this Nothing? ... Does the Nothing exist only because the Not, i.e. the Negation, exists? Or is it the other way around? Does Negation and the Not exist only because the Nothing exists? ... We assert: the Nothing is prior to the Not and the Negation. ... Where do we seek the Nothing? How do we find the Nothing ... We know the Nothing ... Anxiety reveals the Nothing ... That for which and because of which we were anxious, was "really" - nothing. Indeed: the Nothing itself - as such - was present ... What about this Nothing? - The Nothing itself nothings" $"$.

R. Carnap argued that this kind of pseudo-statements stems from the logical defects of language. This is due to the fact that any sentence can be analyzed grammatically and logically. If it is built on the basis of appropriate syntactic rules, it will be formally correct. But this does not mean that it must be logically meaningful, i. e., the opinion it contains must be relevant to the actual state of affairs. Grammatically (formally) correct sentences are easily confused with true sentences because they appear to be similar in natural language. This possibility is eliminated from a logically correct language, because it cannot use the same forms for meaningful and meaningless word sequences.

Moreover, from the R. Carnap's point of view, M. Heidegger operated with terms like Nothing too frivolously. He used this term as

9 Carnap R. The Elimination of Metaphysics Through Logical Analysis of Language / trans. A. Pap. In: Logical positivism / Ayer A. J. (ed.). New York: Free Press, 1959. P. 69.

${ }^{10}$ Ibid. P. 69. 
a name for the subject, while in ordinary language, when we use it, we try not to state that something is present, but rather to state that something is absent, such as in the dialogue: "What is outside?" "Nothing is outside". In this case, it is tempting to think nothing as a real subject which should not happen. It is even more complicated when words are metaphorically used in metaphysics. In such circumstances, even those terms that have a literal meaning lose it. And one can only wonder how "The Nothing nothings" is possible. By the same principle, it was possible to construct other metaphysical sentences, when the mind minds or the word words. However, all such verbs become metaphors that are irrelevant to the actual substance of the case. In addition, metaphysical terms are often contradictory. For example, in the case of the word Nothing, its definition clearly indicates the absence of an object that it indicates. If you use this term in a sentence, the corresponding object will already be recognized as existing. And that is in addition to the fact that this sentence is recognized to be meaningless.

One can try to argue, as M. Heidegger did, that the dissatisfaction with the interpretation of metaphysical judgments from the logical point of view is due to the imperfection of logic, not the falsity of metaphysics itself. It seems that logic is not sufficient for analyzing the basics of being. However, criticizing logic in this way, M. Heidegger used its principles himself. He opposed metaphysics and science, and at the same time used basic scientific tool - logic. Although he assured that it can only be used to some extent - until the moment when you begin to delve into the metaphysical issues. They are subject to principles of a different nature, which are fully understood by the higher mind, but not a human one. It is certainly possible to agree with such a statement if it had a logical argument that would be in line with the empirical principles of science. But this is impossible by definition, since we cannot comprehend things that go beyond the limits of our understanding.

It would be wrong to say that R. Carnap criticized only M. Heidegger's ideas. It was important for him to prove that all metaphysics is meaningless. It also contains other types of logical errors. Thus, R. Carnap drew attention to the difficulties related to the usage of the ambiguous word "to be". It is very common to find this word in metaphysical systems such as M. Heidegger's conception. 
Because the term is used both as a copula prefixed to a predicate in a simple proposition, and as a term that designates the existence of an object, situations may arise when these two use cases are mixed. The interpretation of "existence" as a predicate is erroneous. As a standalone element of proposition it cannot be correlated with the subject and is interrelated with the predicate. This error is present in R. Descartes's “Cogito, ergo sum". In addition, metaphysical statements confuse concepts of different types that cannot be combined because it breaks logical syntax (such as in the statement "Caesar is a prime number", where the subject is a person and the predicate is a type of numbers). Despite the absurdity of this kind of combination of words in the holistic constructions, according to R. Carnap, "Pseudo-statements of this kind are encountered in especially large quantity, e.g., in the writings of Hegel and Heidegger. The latter has adopted many peculiarities of the Hegelian idiom along with their logical faults (e.g. predicates which should be applied to objects of a certain sort are instead applied to predicates of these objects or to "being" or to "existence" or to a relation between these objects)" ". However, the main disadvantage of metaphysics, which makes it meaningless, is not logical contradictions, but rather the lack of reference to empirical facts. Since science itself uses empirical facts, the question arises: what would be left over for philosophy? According to $\mathrm{R}$. Carnap, what remains for philosophy is only a method - a method of logical analysis ${ }^{12}$.

In logical positivism, the process of creating metaphysical judgments can be seen as a kind of combinatorics with abstract concepts. For example, combining in different ways the concepts of "freedom", "truth", "essence" and "being", as already stated ${ }^{13}$, we get all sorts of interesting arguments that "Being of truth is the truth of being", "The essence of truth is truth of essence", "The essence of freedom is the being of truth" etc. Each of them based on the same scheme that underlies M. Heidegger's well-known statement in the lecture "The Essence of Language" (1957): "Das Wesen der Sprache:

11 Carnap R. The Elimination of Metaphysics Through Logical Analysis of Language. P. 73.

12 Ibid. P. 77.

13 Синиця А. С. Розвиток дискусії між представниками континентальної і аналітичної філософії. С. 42. 
Die Sprache des Wesens" ${ }^{\text {"14 }}$. It is important that the meanings we put into them are the result of their formal combination. Such combinatorics is unacceptable at the level of logical analysis - it has nothing to do with the process of formation of meanings in language according to the rules of logical semantics.

Afterwards the method of logical analysis was actively developed by the English thinker A. J. Ayer. He studied in Vienna (1932-1933) and then actively promoted the ideas of Vienna Circle of logical positivism in the world. He clearly explained that the verification principle can be applied as the main criterion of meaning in his first landmark work "Language, Truth, and Logic" $(1936)^{15}$. Therefore, for A. J. Ayer, M. Heidegger's philosophical ideas were unacceptable by definition and he went into open confrontation with him. He did not stop his sharp criticism even in 1988, when he made the following statement in a lecture "A Defence of Empiricism", delivered at the plenary session of the XVIII World Congress of Philosophy in Brighton (England):

"What I want to say now is that the main contentions of such a work as Bradley's Appearance and Reality (Bradley, 1897) are literally nonsensical and that the same is true of much of Hegel's own work, not to speak of the outpourings of such modern charlatans as Heidegger and Derrida. It makes me very sad to learn that their rubbish is acquiring popularity in this country, appealing to those who mistake obscurity for profundity, and find the serious work of such first-rate American philosophers as Quine, Goodman, Putnam and Davidson too difficult" ${ }^{\prime 16}$.

A. J. Ayer's criticism was the result of the rejection of metaphysical ideas. Moreover, metaphysics itself seemed to him a dangerous phenomenon for contemporary philosophy. Because of the popularization of the ideas of unverified metaphysical theories, which are meaningless in essence, the works of those analytic thinkers, who really seemed important to him, remained in the shadows. A. J. Ayer

${ }^{14}$ Heidegger M. Das Wesen der Sprache. In: Heidegger M. Unterwegs zur Sprache. Frankfurt am Main: Vittorio Klostermann, 1985. S. 166.

${ }^{15}$ Ayer A. J. Language, Truth and Logic. London: Victor Gollancz Ltd, 1936. $254 \mathrm{p}$.

Ayer A. J. A Defence of Empiricism. In: A. J. Ayer: Memorial Essays / A. Phillips Griffiths (ed.) Cambridge: Cambridge University Press, 1991. P. 3. 
obviously understood that, given their complexity (first of all, the use of methods of logic and observance of various procedural issues, which significantly limit the flight of fantasy and make it impossible to use metaphors), they looked in a bad light comparing to the writings of continental philosophers.

There were also other reasons, arising from the distinction between analytic and continental philosophizing. The former is focused on the search for truth, on the strict observance of rules and laws of logic, a detailed and consistent analysis, aiming to eliminate any linguistic ambiguities and inaccuracies. Analytic philosophers were not intended to influence public opinion, change the foundations of social life, fight for the minds of people. Therefore, their philosophical ideas were, in fact, not used in the political area. It is another matter with representatives of continental philosophy phenomenology, hermeneutics, post-structuralism, etc. They were not aimed at discovering the truth, but rather at creating it and producing the meanings. Their language was full of metaphors and vivid images. It is not by chance that their ideas have often instigated discussions in various intellectual circles. These ideas were picked up and developed in the field of politics in order to find the philosophical basis for political systems. They were also interesting in the field of literature, because they addressed the problems of human existence, society, communication. However, according to logical positivists, continental philosophers used an inappropriate methodology.

\section{Neutral reception}

A position towards philosophical ideas of M. Heidegger initiated by the English philosopher G. Ryle was more mild. In 1929, he was perhaps the first in the analytic tradition to leave a comment on the views of his German collegue, publishing in "Mind" a review of "Being and Time". It was there that he immediately stated the following: "This is a very difficult and important work, which marks a big advance in the application of the "Phenomenological Method" though I may say at once that I suspect that this advance is an advance towards disaster" $"$.

So, on the one hand, G. Ryle recognized the importance of this work, and on the other one - he warned that the use of the

${ }^{17}$ Ryle G. Sein und Zeit. By Martin Heidegger. Mind. Vol. 38, No. 151. P. 355. 
phenomenological method was dangerous. G. Ryle as an ordinary language philosopher took an interest in studying the natural language, unlike R. Carnap and A. Ayer, who developed the ideas of logical analysis of language. Ordinary language philosophers no longer tried to construct the perfect language, since after Gödel's theorems on incompleteness in the early 1930s, such language appeared to be a vain idea. Any formal language seemed too imperfect and could not capture the full diversity of ordinary language meanings. The ordinary language, for its part, seemed still full of mysteries, the study of which would give a better understanding of how the process of formation and fixation of meanings goes on.

In his review, G. Ryle pointed out that M. Heidegger developed E. Husserl's ideas that would be difficult to understand for the English reader because of the lack of translation of the E. Husserl's works, and the influential predecessors of his logical theory, in particular F. Brentano, B. Bolzano and G. Frege. At that time there were no significant scientific works devoted to the analysis of their conceptions. And without them, it is difficult to understand any of the conclusions in the theory proposed by M. Heidegger. Therefore, G. Ryle was the first one to draw attention in his review to F. Brentano's reasoning and demonstrated how different they were from traditional logical analysis in the interpretation of the nature of judgment. Thus, in logic, judgment is defined as the unity of two terms - the subject and the predicate. For F. Brentano, judgment is an indivisible psychic act, one of three psychic phenomena (the other two are vorstellung and feeling). They are different from the physical phenomena studied within the natural sciences. These ideas were developed by A. Meinong and E. Husserl, and further studied by M. Heidegger). However, to understand the peculiarities of the latter's philosophy, concept of intentionality is also important. It was important to the medieval thinker Duns Scott and was close in content to E. Husserl's term "meaning". It follows that intentional objects should be understood as immanent content of consciousness. For E. Husserl, a theoretical psychologist of the school of Brentano in early period, it was important to demonstrate the fallacy of different psychological theories and to discover the true nature and status of Meaning in the realm of phenomenology. 
It was important for M. Heidegger to find a presupposition of the phenomenology. He sought it in ontology. Therefore, G. Ryle wrote: "The root problem of Phenomenology is the Meaning of Being"18. Instead of giving another definition, it is important to understand the universality of the concept of being, or to understand the specifics of being of individual things.

It should be noted that Ryle is only partially concerned with the analysis of such key problems of "Being and Time" as Dasein (including being-in-the-world) and the intrinsic temporality of human being. Trying to understand what Dasein is (maybe even in the context of a question "What is it to be an I ("Dasein")"?), G. Ryle traditionally defined it as Care (actually explaining Heidegger's "Dasein ist Sorge") - "caring about" or "caring for"19. Temporality is the main feature of human being. However, most of the attention of G. Ryle was not the Being or Time, but the specificity of M. Heidegger's application of the Husserlian phenomenological method. The prospects for this method seem doubtful, since its consistent application, by G. Ryle, leads to self-ruinous subjectivism or windy mysticism, though he added that his understanding of this difficult work was insignificant ${ }^{20}$.

B. Russell was even less interested in studying M. Heidegger's legacy. There is no mention of phenomenology at all in his "A History of Western Philosophy"21 (1945). The final section of the book is devoted to the philosophy of logical analysis, in which B. Russell particularly distinguished the figure of G. Frege. Previously he mentioned only his contemporaries A. Bergson, W. James and J. Dewey. B. Russell has only one reference to M. Heidegger in the "Wisdom of the West" (1959), where he wrote: "Martin Heidegger's philosophy is extremely obscure and highly eccentric in its terminology. One cannot help suspecting that language is here running riot. An interesting point in his speculations is the insistence that nothingness is something positive. As with much else in

${ }^{18}$ Ryle G. Sein und Zeit. By Martin Heidegger. P. 363.

${ }^{19}$ Ryle G. Sein und Zeit. By Martin Heidegger. P. 366.

${ }^{20}$ Ibid. P. 370.

${ }^{21}$ Russell B. A History of Western Philosophy. New York: Simon and Shuster, 1945. XXIII, 895 p. 
Existentialism, this is a psychological observation made to pass for logic"22.

As we can see, B. Russell expressed a fairly traditional view of M. Heidegger's philosophy. He no longer correlated it with the tradition of phenomenology, but wrote clearly about existentialism. B. Russell was in no hurry to admit that the concept of nothingness was meaningless because he understood the motives of existentialism as a challenge to traditional logic. After all, he touched upon rather more historical aspects of socio-political issues in Western philosophy.

\section{Positive reception}

This reception was started by $\mathrm{L}$. Wittgenstein shortly after the publication of "Being and Time". Like B. Russell, L. Wittgenstein directly mentioned M. Heidegger only once. It was in the one of discussions that took place between him and members of the Vienna Circle at F. Weisman's and M. Schlick's homes. These discussions were recorded by F. Weissman and later published in the book "Wittgenstein and the Vienna Circle: Conversations, Recorded by F. Weissman" 23 (1930). Thus, in the record from December 29, 1929, the following reasoning of L. Wittgenstein (translated by P. M. Livingston) stated:

"I can very well think what Heidegger meant about Being and Angst. Man has the drive to run up against the boundaries of language. Think, for instance, of the astonishment that anything exists. This astonishment cannot be expressed in the form of a question, and there is also no answer to it. All that we can say can only, a priori, be nonsense. Nevertheless we run up against the boundaries of language. Kierkegaard also saw this running-up and similarly pointed it out (as running up against the paradox). This running up against the boundaries of language is Ethics. I hold it certainly to be very important that one makes an end to all the chatter about ethics whether there can be knowledge in ethics, whether there are values, whether the Good can be defined, etc. In ethics one always makes the attempt to say something which cannot concern and never concerns

${ }^{22}$ Russell B. Wisdom of the West. London: Bloomsbury Books, 1989. P. 303.

23 Ludwig Wittgenstein und der Wiener Kreis. Gespräche, aufgezeichnet von Friedrich Waismann / von B. F. McGuinness (hrg.). Frankfurt am Main: Suhrkamp, 2001. $265 \mathrm{~s}$. 
the essence of the matter. It is a priori certain: whatever one may give as a definition of the Good - it is always only a misunderstanding to suppose that the expression corresponds to what one actually means (Moore). But the tendency to run up against shows something. The holy Augustine already knew this when he said: "What, you scoundrel, you would speak no nonsense? Go ahead and speak nonsense - it doesn't matter!"24.

Publisher B. F. McGuinness (German edition) related the mention of Being and Angst to L. Wittgenstein with this argument from "Being and Time":

"That in the face of which one has anxiety [das Wovor der Angst] is Being-in-the-world as such. What is the difference phenomenally between that in the face of which anxiety is anxious [sich angstet] and that in the face of which fear is afraid ? That in the face of which one has anxiety is not an entity within-the-world ... the world as such is that in the face of which one has anxiety"25.

In general, the concept of Angst in Heidegger's philosophy signifies a deep metaphysical fear of death, a fear of Nothing that

24 Livingston P. M. Wittgenstein Reads Heidegger, Heidegger Reads Witttgenstein: Thinking Language Bounding World. P. 223-224. In original: «Ich kann mir wohl denken, was Heidegger mit Sein und Angst meint. Der Mensch hat den Trieb, gegen die Grenzen der Sprache anzurennen. Denken Sie z. B. an das Erstaunen, dass etwas existiert. Das Erstaunen kann nicht in Form einer Frage ausgedrückt werden, und es gibt auch gar keine Antwort. Alles, was wir sagen mögen, kann a priori nur Unsinn sein. Trotzdem rennen wir gegen die Grenze der Sprache an. Dieses Anrennen hat auch Kierkegaard gesehen und es sogar ganz ähnlich (als Anrennen gegen das Paradoxon) bezeichnet. Dieses Anrennen gegen die Grenze der Sprache ist die Ethik. Ich halte es für sicher wichtig, dass man all dem Geschwätz über Ethik - ob es eine Erkenntnis gebe, ob es Werte gebe, ob sich das Gute definieren lasse etc. - ein Ende macht. In der Ethik macht man immer den Versuch, etwas zu sagen, was das Wesen der Sache nicht betrifft und nie betreffen kann. Es ist a priori gewiss: Was immer man für eine Definition zum Guten geben mag - es ist immer nur ein Missverständnis, das Eigentliche, was man in Wirklichkeit meint, entspreche sich im Ausdruck (Moore). Aber die Tendenz, das Anrennen, deutet auf etwas hin. Das hat schon, der heilige Augustin gewusst, wenn er sagt: Was, du Mistviech, du willst keinen Unsinn reden? Rede nur einen Unsinn, es macht nichts!» [Ludwig Wittgenstein und der Wiener Kreis. Gespräche, aufgezeichnet von Friedrich Waismann / von B. F. McGuinness (hrg.). Frankfurt am Main: Suhrkamp, 2001. S. 68.].

${ }^{25}$ Heidegger M. Being and Time / trans. by J. Macquarrie and E. Robinson. Cambridge, Mass.: Blackwell, 2001. P. 230-231. 
confronts the Beings and reveals its nature for being of human ${ }^{26}$. Asking about Nothing, the person gets in the realm of metaphysics. In other words, in order to understand the nature of Being, it is necessary to go beyond it, where it encounters Nothing. In other words, in order to understand the nature of Being, one must go beyond its limits, where is Nothing. Under these conditions, the question arises: "Warum ist überhaupt Seiendes und nicht vielmehr Nichts?"27 ("Why are there beings at all, and why not rather nothing?").

But what exactly did L. Wittgenstein tell us, thinking of Being and Angst even in such a trivial way? His reasoning leaves a mixed impression. On the one hand, it becomes clear that L. Wittgenstein, despite belonging to another philosophical tradition, got to know Heidegger's ideas two years after "Being and Time" appeared. And finally he spoke of Heidegger with some respect in the context of those authors who had an influence on his work - Augustine, Kierkegaard or Moore - at least he mentioned them occasionally. On the other hand, one direct mention is clearly not enough for a complete reconstruction of L. Wittgenstein's reasoning. Of course, he generally did not appeal to the works of any other philosopher. Besides, he convinced that language is an obstacle to understanding the basics of being in this particular consideration. Outside of language there are probably some experiences like M. Heidegger's Angst. Therefore, it is better for us to remain silent about ethics. This does not mean that, since ethics judgments are meaningless, L. Wittgenstein does not speak about ethics. He is interested in how we can know the realm of ethics. Therefore, he comes to the awareness of the phenomenon of silence (lack of language), which is not identical with quiet (lack of sounds). The logic of language can only tell us the limits of where the unspeakable begins - all kinds of ethical experiences or intent to find a certain supersensible integrity for a world.

${ }^{26}$ Heidegger M. Was ist Metaphysik. Frankfurt: Vittorio Klostermann, 2007. S. 29 .

${ }^{27}$ Ibid. S. 21. 
It should be noted that J. M. Thompson ${ }^{28}$, looking for potential sources of L. Wittgenstein's phenomenology, also draws attention to his reasoning, dated January 1932, on the possibility of using the sentence "the Nothing nothings" or the question "what was earlier, the Nothing or the negation?",29. In order to understand the sense of such statements, one must first ask their author what he meant, one must understand how he formulated his opinion and whether such an abstraction, as suggested by L. Wittgenstein, was analoguos to island surrounded by the endless sea, where island is Being, and endless sea is Nothing.

Many interpretations of this kind can be offered to explain the origins of L. Wittgenstein's philosophy. However, due to the small number of references to other philosophers in L. Wittgenstein's works, it is difficult to be certain whether the reception of their ideas was indirect, incidental or not essential for understanding the ideas he formulated on his own.

M. Heidegger's influence can be traced more thoroughly to those philosophers who were directly engaged in the study of his work. In particular, M. Heidegger's legacy was explored by R. Rorty, an American thinker who had strong interests in contemporary analytic philosophy. He became interested in continental philosophy as early as the second half of the 1960s. This was due to the fact of the evolution of his views. It is well known that over time he moved from the tradition of pragmatism to post-pragmatism, in which he supplemented the ideas of analytic philosophy with a number of reflections specific to postmodernism and hermeneutics. He was interested in describing a poetic culture, developing the principles of ironic liberalism and anti-representationalism. Not surprisingly, he criticized the analytic project of philosophy in the late period, overestimated the importance of the linguistic turn and looked for new authors who could improve his post-pragmatic approach in philosophy.

${ }^{28}$ Thompson J. M. The Origins of Wittgenstein's Phenomenology. In: Papers of the 31st IWS / A. Hieke, H. Leitgeb (eds). Kirchberg am Wechsel: ALWS, 2008. P. 350-352.

29 Wittgenstein's Nachlass: The Bergen Electronic Edition. Oxford: Oxford University Press, 1998. 
R. Rorty mentioned M. Heidegger for the first time in his "Linguistic Turn", which was published in 1967. In spite of the fact that the work was devoted to the linguistic turn, which was due to the efforts of analytic philosophers, R. Rorty also drew attention to the M. Heidegger's philosophical conception, which he regarded as an "attempt to do philosophy in an entyrely new way"30. Even then R. Rorty was interested in M. Heidegger's philosophy, since his study gave him a better understanding of the essence of the linguistic turn. In the course of time, his interest in the German thinker had only increased. In 1976 he published a work "Essays on Heidegger and Others" $"$. As its name suggests, M. Heidegger has become a key figure worthy of his attention in the context of post-Nietzschean philosophy. He named Others, in particular such philosophers as L. Wittgenstein, J. Derrida, M. Foucault. After all, the key figures for twentieth-century philosophy were, in his view, L. Wittgenstein in analytic philosophy, M. Heidegger in continental European philosophy, and D. Dewey in American pragmatism. The first of them (L. Wittgenstein) belonged to a philosophy focused on science. However, in the later period he became convinced of the futility of this approach, since philosophy does not solve its problems like science. In addition, progress in philosophy is a very dubious thing. Therefore, R. Rorty believed that philosophy as a science has no prospects. Another thing is philosophy as a metaphor: free discourse, not burdened with the requirements of science, the intention of a poetic understanding of reality in philosophy. Such standards of philosophizing are important to M. Heidegger, and they are precisely in line with R. Rorty's ideas about the philosophical search for truth. But according to D. Dewey's approach, philosophy is understood as politics, i. e., as a means to change society for the better and to carry out social reforms ${ }^{32}$.

As for M. Heidegger, R. Rorty offered an extremely unorthodox interpretation of his work. He found historicism, irony, nominalism,

30 Rorty R. Metaphilosophical Difficulties of Linguistic Philosophy. In: The Linguistic Turn: Essays in Philosophical Method / R. Rorty (ed.). Chicago: University of Chicago Press, 1967. P. 34.

31 Rorty R. Essays on Heidegger and Others: Philosophical Papers, Volume 2. Cambridge: Cambridge University Press, 1991. X, 202 p.

32 Ibid. P. 9-26. (Part 1. Philosophy as science, as metaphor, and as politics). 
pragmatism, post-Nietzschean motives in M. Heidegger's philosophy. R. Rorty called him "the greatest theoretical imagination of his time ... an exemplary, gigantic, unforgettable figure" ${ }^{33}$. Although, on the other hand, the constant philosophical appeals to poetry did not make a great poet of $\mathrm{M}$. Heidegger, and the academicness of philosophical statements did not always conform to the spirit of the Nietzschean ideas he developed. He certainly had his own philosophical style. His great merit was the creation of many categories that were unrelated to the realm of epistemology and science. These categories enabled philosophy to gain its own space for discourse and no longer needed to be reduced to other systems of knowledge (science in particular). However, language that is full of neologisms and metaphors only proves that finding the reasons is a form of language game. And in such a game we replace the search for metaphysical causes with the irony of the case. The philosopher rewrites previous vocabularies and creates new ones that consist of words that do not denote entities. The ideas of "Being and Time" become pragmatic, because the vocabulary that creates irony is a means of achieving the universal basis of being. The philosopher creates and this is a practical way of his action in the world. In all sorts of elementary words - Dasein, Befindlichkeit, Sorge - we express the difficulties of being that we know.

This R. Rorty's interpretation caused considerable criticism, which was primarily concerned with attempts to find a common vision of problems between representatives of different philosophical traditions. In this regards, it is advisable to mention the criticism of C. B. Guignon, who wrote: “...it is becoming increasingly clear that Rorty's attempt to enlist Heidegger's thought into the ranks of a vision shared by Dewey, Wittgenstein, Quine, and Sellars tends to mask some of the crucial substantive differences between Heidegger and Rorty" 34 . The author has in mind that in the later period of his work many analytic philosophers foregone from the standards of scientific accuracy in philosophy, and thus became similar to M. Heidegger in their understanding of the aims and objectives of philosophy.

${ }^{33}$ Rorty R. Contingency, Irony, Solidarity. New York: Cambridge University Press, 1989. P. 118.

34 Guignon C. B. On Saving Heidegger from Rorty. Philosophy and Phenomenological Research. 1986. Vol. 46, No. 3. P. 402. 
Moreover, the interpretations of M. Heidegger's philosophy (in particular the history, language, truth, human existence, end of philosophy) that R. Rorty proposed also seemed to be not identical to what Heidegger intended. R. Rorty rather adapts M. Heidegger's reasoning to his own considerations than searches for their true meaning. He smooths the differences between philosophical traditions out too much by his own conclusions when he places the ideas of one of them within other philosophical systems.

Finally, it may be appropriate to make some remarks regarding the interpretation of M. Heidegger's philosophy by H. Dreyfus, one of the researchers of the philosophy of artificial intelligence. This interpretation is important for analytic philosophy because it places the German philosopher's thinking in a slightly different philosophical context - the philosophy of artificial intelligence. In the work "What Computers Can't Do: The Limits of Artificial Intelligence" (1972), he demonstrated the importance of M. Heidegger's reasoning in order to understand the peculiarities of organizing life experiences and to comprehend the creative nature of human thinking. Phenomenological studies indicate the uniqueness of the internal world of the person. Explaining the ideas of the German philosopher, H. Dreyfus noted: "Heidegger tries to account for the pervasive concern organizing human experience in terms of a basic human need to understand one's being. But this analysis remains very abstract. It accounts for significance in general but not for any specific goal or specific significance. Thus Heidegger in effect assimilates all human activity to creative problem solving or artistic creation where we do not fully know what our goal was until we have achieved it"35.

Thus, H. Dreyfus appealed to the M. Heidegger's ideas to justify the fact that the artificial intelligence of the machine could not be identical to human and attempts to create such intelligence were futile. L. Braver calls this response to M. Heidegger's philosophy "success at last" ${ }^{36}$ in comparison with previous attempts by G. Ryle, R. Carnap and R. Rorty, whose analysis was to some extent incorrect and unpromising. But H. Dreyfus, having interpreted M. Heidegger's ideas

${ }^{35}$ Dreyfus H. What Computers Can't Do: The Limits of Artificial Intelligence. New York: Harper \& Row, 1972. P. 188.

36 Braver L. Analyzing Heidegger: A History of Analytic Reactions to Heidegger. P. 251. 
in the field of criticism of artificial intelligence, demonstrated their perspective and importance for the new inquiries that arise in contemporary philosophy.

\section{CONCLUSIONS}

Consequently, the reception of philosophical views of M. Heidegger in analytic philosophy depended on the research methodology applied by the thinker as well as his interpretation of metaphysics. In the logical positivism of R. Carnap and A. Ayer, the philosophical views of M. Heidegger, as related to their metaphysics, were found to be absurd and even detrimental to the progress of philosophy. Thinkers who did not particularly delve into the peculiarities of phenomenology (such as G. Ryle or B. Russell) in connection with their own interests, indicated its ambiguity and dangers, despite recognizing the importance of M. Heidegger's legacy for the advance of philosophy. L. Wittgenstein treated that legacy with respect, since he was always interested in what was outside the language. However, he paid very little attention to the analysis of the ideas of the German philosopher. R. Rorty and H. Dreyfus also commended M. Heidegger's philosophy, although they used it to substantiate their own philosophical conceptions - post-pragmatism and critique of artificial intelligence, respectively - rather than to reconstruct or develop Heidegger's philosophy. In this way, they demonstrated the need for M. Heidegger's ideas for the progress of analytic philosophy in various philosophical directions, including combining it with the ideas of continental philosophy. This again proves the importance of studying the philosophy of M. Heidegger and points to its potential for the conceptual progress of contemporary analytic philosophy.

\section{SUMMARY}

The article is devoted to the study of the specific reception of M. Heidegger's philosophical ideas in analytic philosophy. It is proved that the attitude towards this thinker depended largely on the theoretico-methodological approach developed by certain analytic philosopher. The negative, neutral and positive reception of M. Heidegger's legacy in analytic philosophy is distinguished. It is established that the negative reception in logical positivism 
(R. Carnap, A. J. Ayer) was based on the recognition of the absurdity of metaphysics, the impossibility of empirical verification of its foundations, the confusion and contradiction of its meanings. The neutral reception (G. Ryle, B. Russell) was to identify the strengths and weaknesses of M. Heidegger's philosophy, without a thorough analysis of his philosophy. The positive reception (L. Wittegenstein, R. Rorty, H. Dreyfus) manifested itself in attempts to interpret M. Heidegger's ideas as a means of substantiating their own philosophical conceptions. All this testified to the importance of dialogue between continental and analytic philosophy and the importance of the ideas of the German thinker in it.

\section{REFERENCES}

1. Синиця А. С. Розвиток дискусії між представниками континентальної і аналітичної філософії. Актуальні проблеми духовності: зб. наук. праць. 2016. Вип. 16. С. 36-47.

2. Ayer A. J. A Defence of Empiricism. In: A. J. Ayer: Memorial Essays / A. Phillips Griffiths (ed.) Cambridge: Cambridge University Press, 1991. P. 1-16.

3. Ayer A. J. Language, Truth and Logic. London: Victor Gollancz Ltd, 1936. 254 p.

4. Braver L. Analyzing Heidegger: A History of Analytic Reactions to Heidegger. In: Interpreting Heidegger: Critical Essays / D. O. Dahlstrom (ed.). Cambridge: Cambridge University Press, 2011. P. 235-255.

5. Carnap R. The Elimination of Metaphysics Through Logical Analysis of Language / trans. A. Pap. In: Logical positivism / Ayer A. J. (ed.). New York: Free Press, 1959. P. 60-81.

6. Dreyfus H. What Computers Can't Do: The Limits of Artificial Intelligence. New York: Harper \& Row, 1972. 259 p.

7. Esfeld M. What can Heidegger's Being and Time Tell Today's Analytic Philosophy? Philosophical Explorations. 2001. Vol. 4. P. 46-62.

8. Geier M. Wittgenstein und Heidegger: Die letzten Philosophen. Rowohlt E-Book, 2017. 448 s.

9. Guignon C. B. On Saving Heidegger from Rorty. Philosophy and Phenomenological Research. 1986. Vol. 46, No. 3. P. 401-417. 
10.Heidegger M. Being and Time / trans. by J. Macquarrie and E. Robinson. Cambridge, Mass.: Blackwell, 2001. 589 p.

11.Heidegger M. Das Wesen der Sprache. In: Heidegger M. Unterwegs zur Sprache. Frankfurt am Main: Vittorio Klostermann, 1985. S. 147-204.

12.Heidegger M. Was ist Metaphysik. Frankfurt: Vittorio Klostermann, 2007. 55 s.

13.Livingston P. M. Wittgenstein Reads Heidegger, Heidegger Reads Witttgenstein: Thinking Language Bounding World. In: Beyond the Analytic-Continental Divide: Pluralist Philosophy in the TwentyFirst Century / J. A. Bell, A. Cutrofello, P. M. Livingston (ed.). New York: Routledge, 2015. P. 222-248.

14.Ludwig Wittgenstein und der Wiener Kreis. Gespräche, aufgezeichnet von Friedrich Waismann / von B. F. McGuinness (hrg.). Frankfurt am Main: Suhrkamp, 2001. 265 s.

15. McDaniel K. Heidegger's Metaphysics of Material Beings. Philosophy and Phenomenological Research. 2013. Vol. 87. P. 332-337.

16. Robson J. Heidegger and Analytic Philosophy: Together at Last? International Journal of Philosophical Studies. 2014. Vol. 22, Issue 3: Continental Engagement with Analytic Philosophy. P. 482-487.

17. Rorty R. Contingency, Irony, Solidarity. New York: Cambridge University Press, 1989. XVI, 201 p.

18. Rorty R. Essays on Heidegger and Others: Philosophical Papers, Volume 2. Cambridge: Cambridge University Press, 1991. X, 202 p.

19.Rorty R. Metaphilosophical Difficulties of Linguistic Philosophy. In: The Linguistic Turn: Essays in Philosophical Method I R. Rorty (ed.). Chicago: University of Chicago Press, 1967. P. 1-40.

20.Russell B. A History of Western Philosophy. New York: Simon and Shuster, 1945. XXIII, 895 p.

21.Russell B. Wisdom of the West. London: Bloomsbury Books, 1989. $319 \mathrm{p}$.

22. Ryle G. Sein und Zeit. By Martin Heidegger. Mind. Vol. 38, No. 151. P. 355-370. 
23. Thompson J. M. The Origins of Wittgenstein's Phenomenology. In: Papers of the 31st IWS / A. Hieke, H. Leitgeb (eds). Kirchberg am Wechsel: ALWS, 2008. P. 350-352.

24. Wittgenstein and Heidegger / D. Egan, S. Reynolds, A. J. Wendland (eds.). London: Routledge, 2013. 282 p.

25. Wittgenstein's Nachlass: The Bergen Electronic Edition. Oxford: Oxford University Press, 1998.

\section{Information about the author:} Synytsia A. S., Doctor of Philosophy, Professor at the Department of History of Philosophy, Ivan Franko National University of Lviv 1, Universytetska str., Lviv, 79000, Ukraine 